\title{
Gender differences in access and use of selected productive resources among sweet potato farmers in Uganda
}

Joshua Sikhu Okonya ${ }^{1 *}$ and Jürgen Kroschel ${ }^{2}$

\begin{abstract}
Background: In spite of women making up the biggest workforce in food production, processing and preparation in Africa, little is known about how women access production resources, especially concerning sweet potato enterprise. Based on the sex of the household head, we compared male and female sweet potato farmers' access to agricultural information, credit and extension in Uganda. Differences in sweet potato production techniques, contribution of sweet potato to household food security or cash income, off-farm income sources and membership to farmers' group were also determined.
\end{abstract}

Methods: A diagnostic survey was conducted using a questionnaire in six districts of Uganda. A total of 139 and 53 male- and female-headed households were interviewed, respectively. The study was largely descriptive and data was analyzed using the SAS package.

Results: Few male- (5.8\%) and female- (7.5\%) headed households used fertilizers. Over $80 \%$ of both male- and female-headed households grew sweet potato primarily for home consumption. Only a few male- (8.6\%) and female- (9.4\%) headed households had received any form of agricultural information related to sweet potato production, marketing or value addition in the 12 months preceding the survey. Information sources on sweet potato cropping were numerous, with both farmers' own experience and friends or relatives ( 8.3 and $40.0 \%$ for male- and female-headed households, respectively) being equally the most common. Although none of the female-headed households received agricultural information from both governmental extension agents and non-governmental organizations, male- and female-headed households had similar chances of receiving information. More female-headed households had no off-farm income (67.9\%) and lacked access to credit (26.4\%) than did their male counterparts. Male-headed households had significantly more members who belonged to a farmer organization (44.6\%) compared to female-headed households (30.2\%).

Conclusions: Both male- and female-headed households were found to have relatively equal but very low access to both agricultural information and credit. There is a need to develop and disseminate integrated sweet potato management messages for better understanding and efficient use, preferably in local languages and through mass media. There is evidence of anti-female household heads' bias in membership to farmer organizations. It is recommended that men receive training on gender mainstreaming and awareness, so as to appreciate the role women play in the sweet potato value chain.

Keywords: Farmer perceptions, Household food security, Female-headed households, Rural development

\footnotetext{
* Correspondence: j.okonya@cgiar.org

${ }^{1}$ Global Program of Integrated Crop and Systems Research, International

Potato Center (CIP), PO Box 22274, Kampala, Uganda

Full list of author information is available at the end of the article
} 


\section{Introduction}

In Uganda, about a third of the population lives in extreme poverty. Most households depend on rain-fed agriculture as their main source of income, with the agricultural sector employing over three-quarters of the labor force ( $83 \%$ of women and $71 \%$ of men) but only accounting for $24 \%$ of gross domestic product [1]. Women contribute $70 \%$ to $75 \%$ of agricultural food production. A survey conducted in 2009 [2], reported that 6.3\% households in Uganda were food insecure and $21.3 \%$ households were at risk of becoming food insecure. In 2005, the average intake per person per day $(1,971)$ was still far below the value of 2,300 calories recommended by the World Health Organization (WHO). Most agricultural production is by poor farmers, who depend on sweet potato (Ipomoea batatas (L.) Lam.) as their primary source of food and income.

Sweet potato is globally the sixth most important food crop after rice (Oryza spp.), wheat (Triticum aestivum L.), potato (Solanum tuberosum L.), maize (Zea mays L.) and cassava (Manihot esculenta Crantz), but it is the fifth most important food crop in developing countries [3]. Each year, more than 105 million metric tons of sweet potato are produced worldwide, with $95 \%$ of this being grown in developing countries. In Uganda, as in many other countries in sub-Saharan Africa, sweet potato is mainly cultivated by women and often referred to as a 'female crop' [4]. Sweet potato is important as a staple and food security crop in many countries in Africa.

Achieving food security is a prerequisite to realizing the first and the third United Nations millennium development goals (MDGs) that are concerned with reducing the proportion of people who suffer from hunger and, promoting gender equality and empowering women, respectively [5]. In Africa's agricultural sector, women are responsible for producing $80 \%$ of the food, as opposed to men who tend to engage more in incomegenerating activities such as cash crop production, perhaps because of their responsibility of availing food for the family $[6,7]$. Despite this essential contribution to household food production and provision, access to resources such as appropriate technologies, modern farming methods, markets, credit and extension services for women is limited [8].

Several studies have shown that access to information is vital for improving agricultural production $[9,10]$ especially in rural areas where agriculture is the main source of livelihood. Oladele [10] points to language as one of the main factors influencing access to agricultural information disseminated through radio and television in Nigeria. The language of radio and television broadcasts in an ethnically diverse country such as Uganda may increase agricultural information uptake by farmers, compared to use of official languages that are not understood by most farmers.
Gender of household heads, as revealed in a study conducted in Ethiopia [11], influenced participation in governmental extension programs, with male-headed households taking dominance $(75 \%)$. Factors such as age, farm size, religion, education level and income were reported to have a significant effect on accessibility to extension services by women [12]. Technology adoption among cowpea (Vigna unguiculata (L.) Walp.) growers in Uganda was however, shown not to be influenced by gender [13].

Gender is a key factor in explaining the variation in access to social services in rural low-income communities in Uganda; it would therefore be useful to separately analyze accessibility of male- and female-headed households to social support services [14] in sweet potato production. Much as women are greatly involved in the sweet potato value chain in Uganda, factors such as culture, traditions, gender roles and responsibilities, and land ownership could be affecting the access of women sweet potato farmers to agricultural information or credit in Uganda. Observations of gender-biased access to agricultural information, extension services or credit have been observed in Sudan [8], Malawi [12], Nigeria [15], and Kenya [16]. The fact that women are often involved in household chores gives them little time to receive extension services, unlike their male counterparts [17]. Little or no detailed individual information on empirical studies on women sweet potato farmers' access to and use of agricultural information, credit and extension services in Uganda is available. The lack of such information is therefore an obstacle to reducing gender bias in access to social services and consequently hinders poverty reduction and economic development programs.

The contribution of women to food security cannot be overlooked. There is a need for access to proper and relevant agricultural information, credit and extension services if sweet potato production is to be increased. An understanding of gender differences in accessibility may go a long way in explaining barriers to technology adoption and factors facilitating sweet potato production.

We have previously shown that, in general, socioeconomic factors are perceived to influence farmers' perception to climate change [18]. In this paper, we attempt to establish whether socioeconomic and demographic individual characteristics, specifically gender, influence sweet potato production among smallholder farmers. The current study is part of a bigger research project aimed at understanding how farmers perceive the effects of changes in climatic variables, and how they have adjusted their farming practices to cope with the changes in climate. We aim to highlight gender differences that are often overlooked in sweet potato production and also access to crop production resources. We assume that male- and female-headed households do not have similar crop production skills or 
access to resources that would increase crop production and productivity. We also believe that comparisons between male- and female-headed households are key to explaining differences in market, training, production, new technology adoption and information access.

This study therefore attempted to provide answers to the following questions: what are the current sweet potato production techniques in Uganda? What is the level of access of female-headed households to agricultural information, credit and extension? Specifically, the objectives of the study were to: (1) document the current farmers' sweet potato production practices and techniques in the study districts; (2) determine the level of access and sources of: (i) agricultural information, (ii) credit and (iii) extension; (3) explore which services individual sweet potato farmers are using from extension service providers; and (4) assess the role of agricultural social networks among sweet potato farmers.

\section{Methods}

A diagnostic and descriptive survey was conducted from August to October 2011 across six agro-ecological zones (AEZ) or regions to get wide coverage of sweet potato production among the male- and female-headed households in relation to production resources. In each AEZ, the district with the most sweet potato production was purposely selected: Northern Farming System (Gulu), South Western Highlands (Kabale), Western Range Lands (Kasese), Lake Albert Crescent (Masindi), Eastern Savannah (Soroti) and Lake Victoria Crescent (Wakiso) agro-ecological zones. A total of 192 sweet potato farmers ( 6 districts $\times 2$ subcounties $\times 4$ parishes $\times 4$ villages $)$ were selected with guidance from the district agricultural officers (DAOs). The interviews covered household characteristics, farmers' sweet potato production techniques, membership to an agricultural social network, kinds of support received from social networks, access to- and sources of- agricultural information and, frequency of receiving information on sweet potato cropping. Verbal informed consent was sought from the respondents prior to the beginning of the interview. No ethical approval of the questionnaire used in this study was needed because it was non-intrusive, did not involve any ethical dilemmas and did not involve any degree of risk of harm to the farmers. The data were disaggregated to show the trends in the two different household-headed categories. Descriptive analyses (frequency, percentages and means) were carried out using the statistical program SAS V.9.2 for Windows (SAS, Cary, NC, USA) [19]. The significance level was set at $P<0.05$. The $X^{2}$ test was used to examine whether the obtained data and their differences were significant, or whether variables were related to each other. The results were then presented in tables and charts separately for male- and female-headed households, from which inferences were drawn.

\section{Results and discussion}

\section{Sweet potato production techniques}

Sweet potato was grown in two seasons, with the exception of Soroti district that had just one cropping season (Figure 1). Farmers who had access to swampland did not observe any season because they were able to plant sweet potato mostly during the dry seasons when the demand for the roots is high. Piecemeal harvesting was common and this extended harvesting periods by up to 6 months in Masindi, 7 months in Gulu, Soroti and Wakiso and 8 months in Kabale and Kasese. Maturity periods were longest in Kabale district (3 to 10 months) due to the low temperatures and were shortest in Kasese (2 to 5 months).

At farm level, intercropping sweet potato was a common practice by both male- and female-headed households, $41.2 \%$ and $42.2 \%$, respectively (Table 1 ). There was no significant relationship $\left(\chi^{2}=0.0001, P=0.9922\right)$

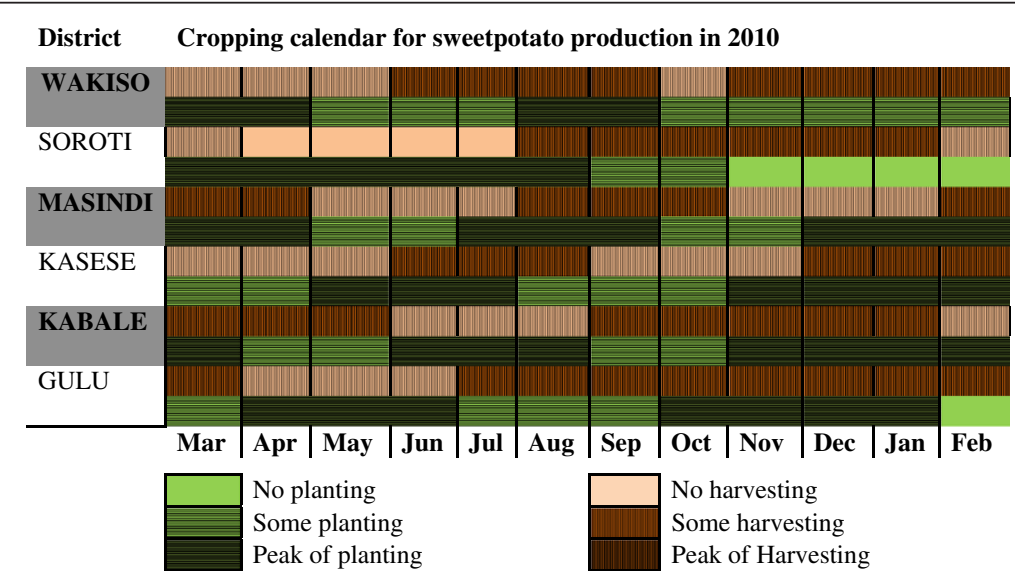

Figure 1 Cropping calendar for sweet potato production in Uganda. 
Table 1 Current farmers' production practices/techniques for sweet potato in the study areas

\begin{tabular}{lccccc}
\hline Characteristic & $\begin{array}{c}\text { Male-headed } \\
\text { households } \\
\text { (\% yes) }\end{array}$ & $\begin{array}{c}\text { Female-headed } \\
\text { households } \\
\text { (\% yes) }\end{array}$ & $\boldsymbol{X}^{2}$ & DF & $\boldsymbol{P}$ value \\
\hline $\begin{array}{l}\text { Intercrop sweet } \\
\text { potato }\end{array}$ & 41.2 & 42.2 & 0.0001 & 1 & 0.992 \\
\hline Use of fertilizers & 5.8 & 7.5 & 0.241 & 1 & 0.623 \\
\hline $\begin{array}{l}\text { Practice crop } \\
\text { rotation }\end{array}$ & 99.3 & 92.3 & 7.218 & 1 & 0.007 \\
\hline $\begin{array}{l}\text { Use of hired } \\
\text { labor }\end{array}$ & 29.5 & 56.6 & 3.476 & 1 & 0.062 \\
\hline $\begin{array}{l}\text { Use of family } \\
\text { labor }\end{array}$ & 99.3 & 100.0 & 0.389 & 1 & 0.533 \\
\hline $\begin{array}{l}\text { Use of variety } \\
\text { mixtures in } \\
\text { sweet potato }\end{array}$ & 89.9 & 81.1 & 0.301 & 1 & 0.584 \\
\hline $\begin{array}{l}\text { Irrigate sweet } \\
\text { potato }\end{array}$ & 10.0 & 0.0 & 0.329 & 1 & 0.567 \\
\hline
\end{tabular}

between sex of the household head and the practice of intercropping sweet potato. Sweet potato/beans (Phaseolus vulgaris L.) was the most common form of intercropping followed by sweet potato/maize, and sweet potato/ cassava. These findings are in line with what Bashaasha et al. [20] reported for districts of Kabale, Gulu and Wakiso. In addition, however, it was observed that more crops are being intercropped with sweet potato. These were cowpea, garden pea (Pisum sativum L.), potato and sorghum (Sorghum bicolor (L.) Moench). The ability of sweet potato to quickly and vigorously produce dense foliage that rapidly covers the ground and outcompetes weeds is one of the reasons why it is a good candidate for intercropping [21]. Intercrops are also popular among smallholder farmers because they stabilize the household food supply throughout the year and improve land productivity.

Fertilizer use in sweet potato fields was very low (5.8 and $7.5 \%$ by male- and female-headed households, respectively). There was no significant relationship $\left(\chi^{2}=\right.$ $0.241, P=0.623$ ) between sex of the household head and use of fertilizers in sweet potato fields. Farmers explained that application of fertilizers in sweet potato fields not only reduced root yields but was also not cost effective due to the low market value of roots. Farmers further stated that sweet potato still yielded well without the use of fertilizers and there was therefore no need for fertilizers. The ability of sweet potato to grow in marginal environments and produce an acceptable yield is one major reason why farmers in Africa seldom apply fertilizers in sweet potato fields [22]. Because sweet potato root yields would be boosted with fertilizer application, rotational cropping has been recommended to make sweet potato benefit from residual fertilizers applied in other high value crops in a rotation system [23]. Besides, intercrops of sweet potato and legume crops, such as cowpea, garden pea or beans, would also improve soil fertility.

Male-headed households practiced crop rotation on their farms more than female-headed households (99.3 and $92.3 \%$ male- and female-headed households, respectively). The relationship between sex of the household head and crop rotation was significant $\left(\chi^{2}=7.218\right.$, $P=0.007)$. None of the female-headed households irrigated their sweet potato fields and only $10 \%$ of the maleheaded households practiced irrigation mainly in sweet potato nurseries. Irrigation was mostly performed by hand using water cans. There was no significant relationship $\left(X^{2}=0.329, P=0.567\right)$ between sex of the household head and irrigation of sweet potato. Irrigation rates in Uganda are very low, with only $3.6 \%$ of the total irrigation potential [1]. Lack of money to invest in irrigation systems mainly due to poverty was the main barrier. However, farmers with swampland were able to benefit from sale of sweet potato vines at the start of the cropping system. There was no significant relationship $\left(\chi^{2}=0.301, P=\right.$ 0.584 ) between sex of the household head and growing sweet potato variety mixtures. Over $80 \%$ of the households grew more than one variety of sweet potato in the same garden $(89.9$ and $81.1 \%$ male- and female-headed households, respectively). There was no significant difference $(P=0.345)$ between the average number of sweet potato varieties grown by male- and female-headed households $(3.486 \pm 0.13$ and $3.240 \pm 0.22$, respectively). However, the highest number of sweet potato varieties grown by male- and female-headed households was ten and seven, respectively. Variety mixtures have been reported elsewhere to stabilize and increase crop yields in cowpea [24] and suppress diseases [25]. Bashaasha et al., [20] pointed out that farmers grew sweet potato in mixtures due to shortage of vines, the desire to extend harvesting periods, the need to stabilize root yield and to improve household food security.

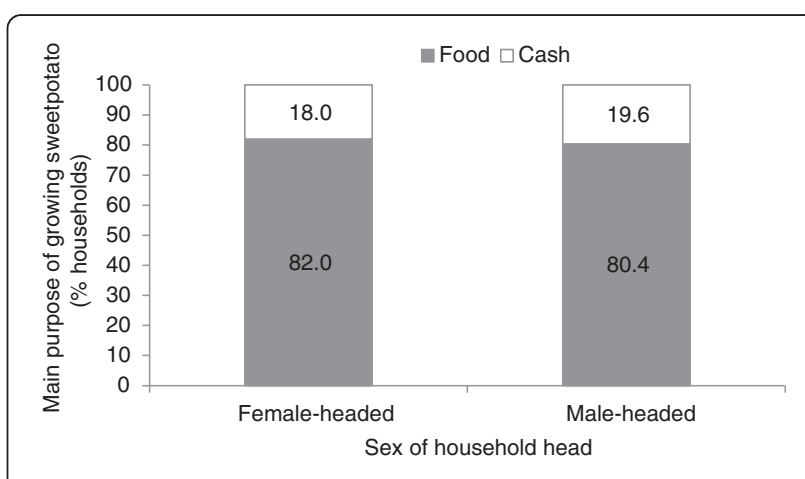

Figure 2 Primary purpose of growing sweet potato. 


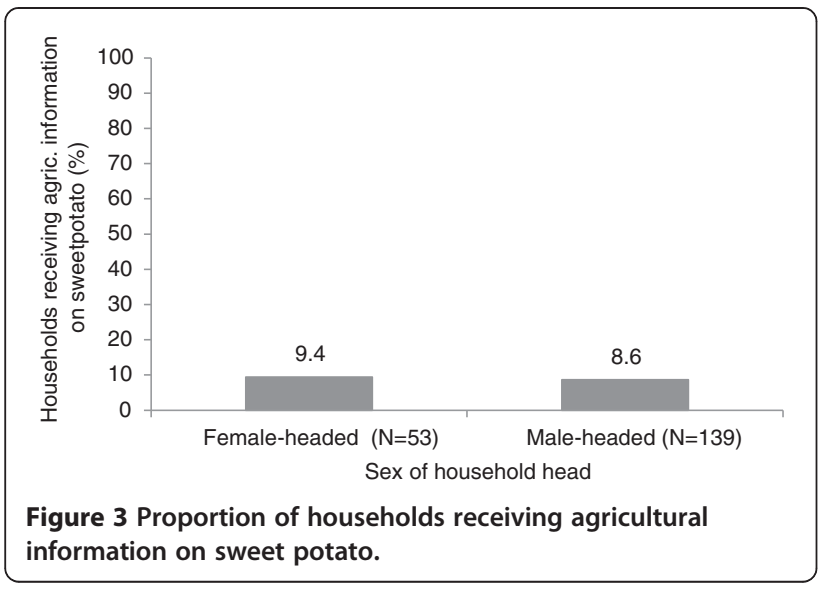

\section{Contribution of sweet potato to household food security and cash income}

Over $80 \%$ of the sweet potato grown was used for home consumption, which further emphasizes the importance of sweet potato as a food security crop across the country (Figure 2). There was no significant difference between male- and female-headed households $(P=0.619)$ in the percentage of sweet potato grown mainly for food $(80.40 \pm 2.32$ and $82.60 \pm 3.65$, respectively) or for cash $(19.60 \pm 2.32$ and $17.40 \pm 3.65$, respectively). In Kabale district, Kashaija and Wagoire [26] reported that sweet potato was the number one food security crop. This is true in most districts of Uganda and sweet potato finds its highest importance in the Eastern districts of Serere, Soroti and Kumi where it is extensively grown for commercial purposes [27]. The role of sweet potato in food systems of Ugandans, together with its potential to not only increase household cash incomes but reduce vitamin A deficiency calls for an investment by both governmental and non-governmental organizations.

The role of women in not only food crop production but also food processing, preservation and preparation has been reported in many African countries including Sudan [28] and Ghana [7]. This notion of women's and men's crops was found to be plastic, since men tend to switch to crops that become commercially lucrative leaving women in charge of producing crops for home consumption [29].

\section{Access to and use of agricultural information}

Generally, few households (8.60 and $9.43 \%$ of male- and female-headed households, respectively) received any form of agricultural information related to sweet potato production, marketing or value addition in the last 12 month preceding this survey (Figure 3 ). The $\chi^{2}$ results revealed no significant relationship $\left(\chi^{2}=0.026, P=0.873\right)$ between sex of household head and access to agricultural information. This low access to agricultural information regarding sweet potato farming is worrying, because it can result in low technology adoption. This implies that most farmers continue to use indigenous farming methods for crop production, a factor that may explain the low onfarm root yields and high losses due to insect pest damage (Okonya and Kroschel, unpublished results). Emphasis needs to be put on providing farmers with modern integrated crop management methods such as the use of clean planting materials, appropriate agronomic practices, soil fertility and pest management [22]. There is therefore a need for national agricultural research systems to develop and disseminate appropriate integrated crop management practices suited to farmers. Yakubu et al. [30] proposed the use of information and communication technologies by both researchers and extension agents being the most efficient way of information transfer. The authors recommend the use of cell phones in information dissemination since most rural communities have access to cell phones [31]. The findings of this study are contrary to the unequal access to extension services by women that has been reported elsewhere in Africa [6,15,17]. Reasons advanced for low access to agricultural information by female farmers included illiteracy, religion or cultural barriers, gender bias, and immense gender-specific responsibilities that include taking care of children, ensuring that the family has food and doing household chores $[6,9,15,17]$.

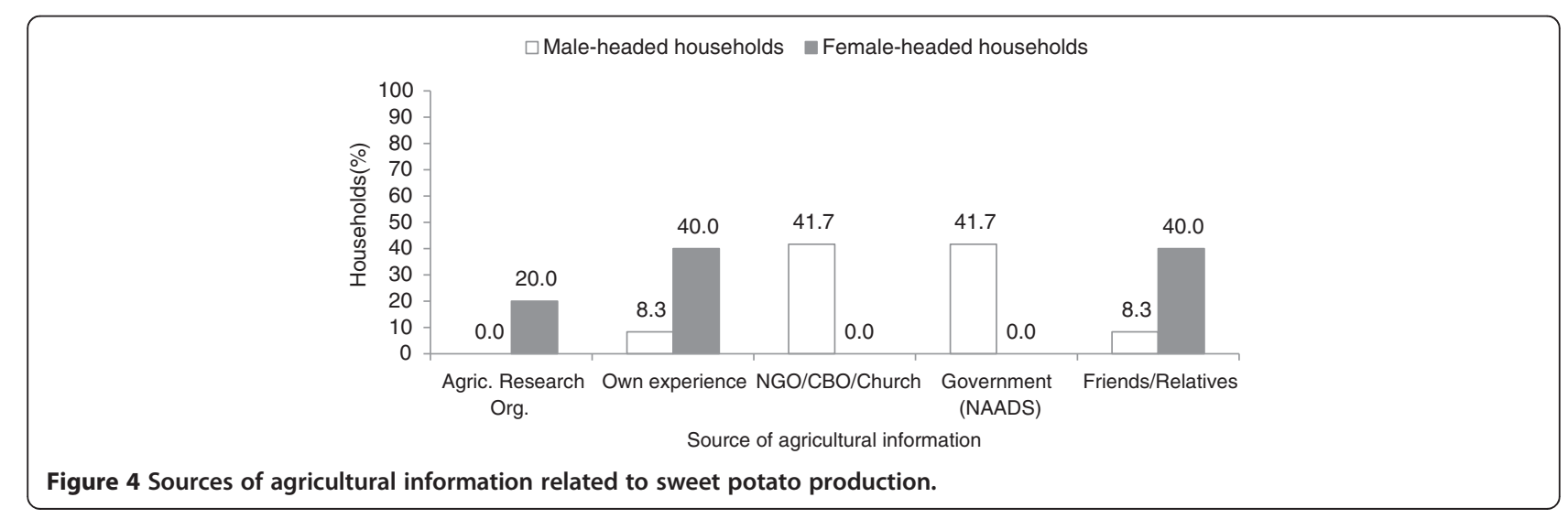




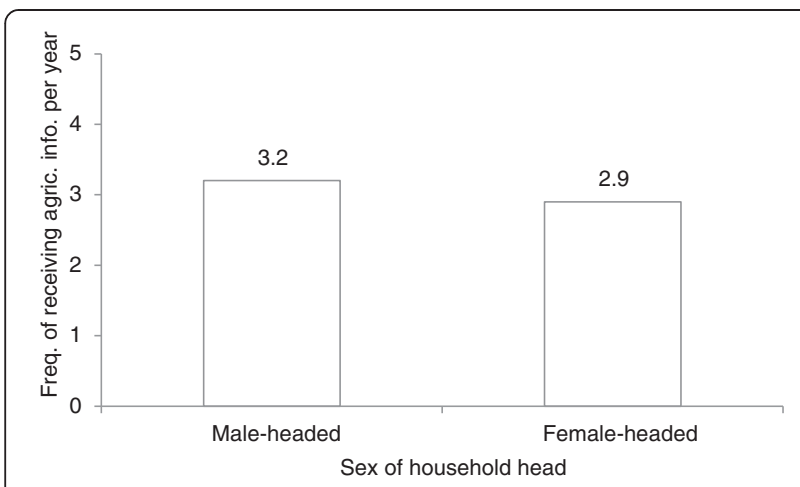

Figure 5 Average number of times in a year when information about sweet potato cropping was received.

Information sources were varied but were mainly friends/ relatives $(8.3 \%$ and $40.0 \%$ for male and female-headed households, respectively), and farmers' own experience (8.3\% and $40.0 \%$ for male- and female-headed households, respectively) (Figure 4). Although none of the female-headed households received agricultural information from the governmental extension agents (National Agricultural Advisory Services (NAADS)) and non-governmental organizations (NGOs), male- and female-headed households had similar chances of receiving information from any of the five information sources $\left(\chi^{2}=10.578, P=0.060\right)$. Agricultural information and specifically information about sweet potato needs to be communicated through more sources such as mass media (radio, television) and preferably in local languages if it is to find a wider audience $[30,32]$.

Though not significant $(P=0.906)$, the frequency of receiving agricultural information was higher in the female-headed households than in their male counterparts (3.20 \pm 2.20 and $2.92 \pm 1.23$, respectively) (Figure 5). In Ethiopia, however, male household heads were more likely to receive advice from extension agents than female household heads [33]. The type of agricultural extension information that households received included best cropping practices especially for new or high

Table 2 Farmers' access to different services provided by extension agents

\begin{tabular}{|c|c|c|c|c|}
\hline \multirow{2}{*}{$\begin{array}{l}\text { Type of information/no. } \\
\text { of times it was received } \\
\text { in a year }\end{array}$} & \multicolumn{2}{|c|}{$\begin{array}{l}\text { Male-headed } \\
\text { households }\end{array}$} & \multicolumn{2}{|c|}{$\begin{array}{l}\text { Female-headed } \\
\text { households }\end{array}$} \\
\hline & $f$ & Responses, \% & $f$ & Responses, \% \\
\hline $\begin{array}{l}\text { Best cropping practices for } \\
\text { new varieties }\end{array}$ & 3 & 25.0 & 2 & 40.0 \\
\hline Best cropping practices & 7 & 58.3 & 3 & 60.0 \\
\hline Pest and disease management & 1 & 8.3 & 0 & 0.0 \\
\hline Post-harvest handling of roots & 1 & 8.3 & 0 & 0.0 \\
\hline Total & $12^{a}$ & 100 & $5^{a}$ & 100 \\
\hline
\end{tabular}

${ }^{\mathrm{a}}$ Total number of responses ( $\mathrm{f}$ ) may be more than 100 due to multiple responses.
Table 3 The top most important off-farm income sources

\begin{tabular}{|c|c|c|c|c|}
\hline \multirow[t]{2}{*}{ Off-farm income activity } & \multicolumn{2}{|c|}{$\begin{array}{l}\text { Male-headed } \\
\text { households }\end{array}$} & \multicolumn{2}{|c|}{$\begin{array}{l}\text { Female-headed } \\
\text { households }\end{array}$} \\
\hline & $f$ & $\begin{array}{c}\text { Responses, } \\
\%\end{array}$ & $f$ & $\begin{array}{c}\text { Responses, } \\
\%\end{array}$ \\
\hline None & 72.0 & 51.8 & 36 & 67.9 \\
\hline Loan from credit institution & 1.0 & 0.7 & 0 & 0.0 \\
\hline Remittances & 1.0 & 0.7 & 2 & 3.8 \\
\hline $\begin{array}{l}\text { Formal/salaried employment } \\
\text { (drivers, teachers and factory } \\
\text { workers) }\end{array}$ & 17.0 & 12.2 & 3 & 5.7 \\
\hline Casual worker & 6.0 & 4.3 & 3 & 5.7 \\
\hline Stone quarrying & 0.0 & 0.0 & 2 & 3.8 \\
\hline Brewing alcohol & 3.0 & 2.2 & 0 & 0.0 \\
\hline $\begin{array}{l}\text { Small business (retail shop, } \\
\text { restaurant, buying and } \\
\text { selling of agricultural } \\
\text { produce in markets) }\end{array}$ & 26.0 & 18.7 & 4 & 7.5 \\
\hline Mechanic (bicycle repair) & 1.0 & 0.7 & 0 & 0.0 \\
\hline $\begin{array}{l}\text { Transport (motorbike riding } \\
\text { as taxi service) }\end{array}$ & 3.0 & 2.2 & 0 & 0.0 \\
\hline Brick laying & 2.0 & 1.4 & 0 & 0.0 \\
\hline Charcoal burning & 2.0 & 1.4 & 1 & 1.9 \\
\hline Handcraft making & 2.0 & 1.4 & 2 & 3.8 \\
\hline Tailoring & 3.0 & 2.2 & 0 & 0.0 \\
\hline Total & $139.0^{\mathrm{a}}$ & 100 & $53^{a}$ & 100 \\
\hline
\end{tabular}

aTotal number of responses (f) adds up to 192 due to single responses by each respondent.

yielding varieties, crop management, pest control and post-harvest handling of sweet potato roots (Table 2).

\section{Off-farm income sources}

Over $50 \%$ of households visited did not have any off-farm income source and relied solely on sale of farm produce as a source of income (Table 3). None of the femaleheaded households received a cash loan from a commercial bank in the 12 months preceding the current study. More female-headed households (67.9\%) lacked an offfarm income source compared to their male counterparts

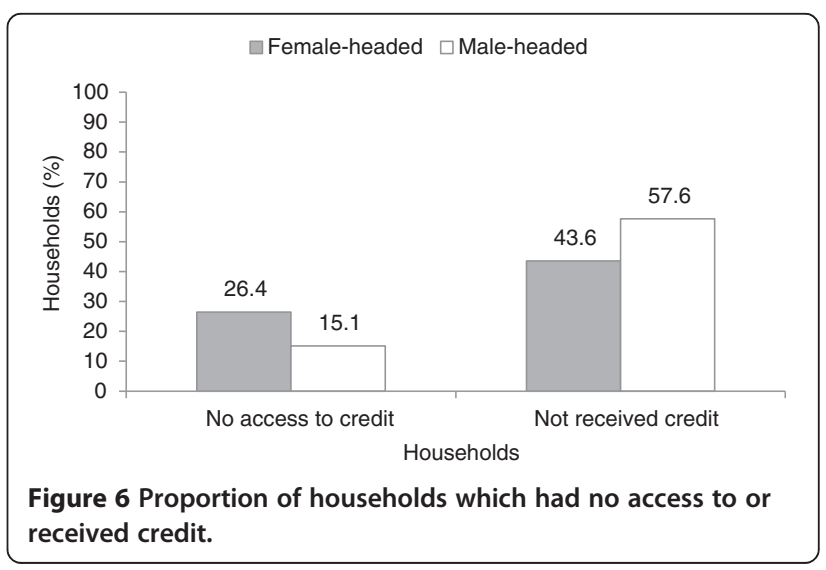




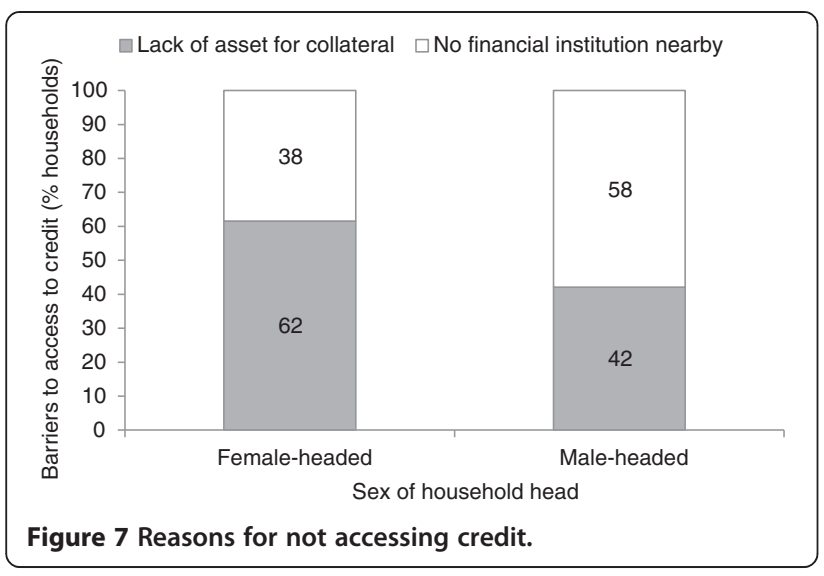

(51.8\%). This difference was however not statistically significant $\left(X^{2}=19.959, P=0.096\right)$. Gender disparity in access to off-farm income has been reported for rural households in Mexico [34]. In Mexico, distance to urban centers and education did not favor women participation in off-farm activities. Off-farm activities are seen as a coping strategy to mitigating or spreading risk in case of total crop failure. However, poverty among these rural households remains a barrier to investing in off-farm activities. FernandezCornejo et al., [35] showed that off-farm income not only adds to household income but also improves the overall economic performance of the farm household. Additionally, it was further argued that increases in off-farm income were significantly and positively related to adoption of technologies that economize on management time. In Mexico, de Janvry and Sadoulet [34] showed that off-farm activities contributed to more than half of the household income. Off-farm income is therefore central in alleviating poverty among rural households. In the Tigray region of Northern Ethiopia, farmers involved in better paying off-

Table 4 Sources of credit

\begin{tabular}{|c|c|c|c|c|}
\hline \multirow[t]{2}{*}{ Credit institution } & \multicolumn{2}{|c|}{$\begin{array}{l}\text { Male-headed } \\
\text { households }\end{array}$} & \multicolumn{2}{|c|}{$\begin{array}{l}\text { Female-headed } \\
\text { households }\end{array}$} \\
\hline & $f$ & Responses, \% & $f$ & Responses, \% \\
\hline Commercial bank & 10 & 19.2 & 3 & 13.6 \\
\hline Farmer group & 8 & 15.4 & 2 & 9.1 \\
\hline Microfinance & 10 & 19.2 & 2 & 9.1 \\
\hline $\begin{array}{l}\text { Non-governmental } \\
\text { organization }\end{array}$ & 4 & 7.7 & 2 & 9.1 \\
\hline Friends/neighbors/relatives & 2 & 3.8 & 3 & 13.6 \\
\hline $\begin{array}{l}\text { Savings and Credit } \\
\text { Cooperative Organizations } \\
\text { (SACCO) }\end{array}$ & 16 & 30.8 & 7 & 31.8 \\
\hline Women's group & 2 & 3.8 & 3 & 13.6 \\
\hline Total & $52^{a}$ & 100 & $22^{a}$ & 100 \\
\hline
\end{tabular}

${ }^{\mathrm{a}}$ Total number of responses (f) may be more than 100 due to multiple responses.
Table 5 Purpose of getting credit

\begin{tabular}{|c|c|c|c|c|}
\hline \multirow[t]{2}{*}{ Credit purpose } & \multicolumn{2}{|c|}{$\begin{array}{l}\text { Male-headed } \\
\text { households }\end{array}$} & \multicolumn{2}{|c|}{$\begin{array}{l}\text { Female-headed } \\
\text { households }\end{array}$} \\
\hline & $f$ & Responses, \% & $f$ & Responses, \% \\
\hline Small business capital & 13 & 18.8 & 9 & 30.0 \\
\hline Education (pay school fees) & 13 & 18.8 & 4 & 13.3 \\
\hline $\begin{array}{l}\text { Buy farm inputs (seeds, } \\
\text { chemicals) }\end{array}$ & 19 & 27.5 & 7 & 23.3 \\
\hline Payment for farm labor & 12 & 17.4 & 6 & 20.0 \\
\hline Personal (medical and home) & 12 & 17.4 & 4 & 13.3 \\
\hline Total & $69^{a}$ & 100.0 & $30^{\mathrm{a}}$ & 100.0 \\
\hline
\end{tabular}

${ }^{\mathrm{a}}$ Total number of responses (f) may be more than 100 due to multiple responses.

farm activities were more likely to hire farm labor and purchase farm inputs [36].

\section{Access to and utilization of credit}

More female-headed households lacked access to credit (26.4\%) compared to $15.1 \%$ of male-headed households (Figure 6). However, sex of the household head did not seem to significantly influence access to credit $\left(\chi^{2}=\right.$ 3.208, $P=0.073)$. Not all respondents who had access to credit actually received credit from financial institutions. A larger proportion of both male- and female-headed households had not received credit and yet had access to credit (57.6 and $43.6 \%$, respectively). Similarly, there was no significant relationship between sex of the household head and ability to receive credit $\left(\chi^{2}=2.201, P=0.138\right)$. The need for productive resources such as land, information, education and credit is central to achieving agricultural oriented livelihood development [37]. Empirical studies have shown that unless women are specifically targeted, numerous factors hinder them from equally accessing credit from microfinance institutions [38]. It is further urged that cash loans received by women have positive impacts on household nutrition, health and education unlike credit received by men. Even in the same household, women in rural Paraguay reported being credit constrained and yet their husbands claimed to have adequate access to credit [38]. Since credit relaxes the financial burden of a farmer, it goes a long way towards facilitating crop production and farm productivity by enabling the farmer to easily hire labor, use improved

Table 6 Amount of credit received

\begin{tabular}{lcccc}
\hline $\begin{array}{l}\text { Gender of household } \\
\text { head }\end{array}$ & \multicolumn{3}{c}{$\begin{array}{c}\text { Amount of credit received } \\
\text { (UGX) }\end{array}$} & SE \\
\cline { 2 - 4 } & Minimum & Mean & Maximum & \\
\hline $\begin{array}{l}\text { Female-headed } \\
\text { households }(\mathrm{N}=20)\end{array}$ & 10,000 & $288,250^{\mathrm{a}}$ & $1,500,000$ & 79,536 \\
\hline $\begin{array}{l}\text { Male-headed households } \\
(\mathrm{N}=50)\end{array}$ & 10,000 & $1,072,720^{\mathrm{a}}$ & $14,000,000$ & 341,288 \\
\hline
\end{tabular}

Exchange rate as per September 2011: US\$1 = UGX2, 500.

${ }^{\text {a } M e a n ~ v a l u e s ~ w i t h ~ t h e ~ s a m e ~ l e t t e r ~ a r e ~ n o t ~ s i g n i f i c a n t l y ~ d i f f e r e n t ~ a t ~} P=0.05$. 
Table 7 Reasons why households that had access to credit did not receive it

\begin{tabular}{|c|c|c|c|c|}
\hline \multirow[t]{2}{*}{$\begin{array}{l}\text { Reasons for not } \\
\text { receiving credit }\end{array}$} & \multicolumn{2}{|c|}{$\begin{array}{l}\text { Male-headed } \\
\text { households }\end{array}$} & \multicolumn{2}{|c|}{$\begin{array}{c}\text { Female-headed } \\
\text { households }\end{array}$} \\
\hline & $f$ & Responses, \% & $f$ & Responses, \% \\
\hline $\begin{array}{l}\text { Too much paperwork/ } \\
\text { lengthy procedure }\end{array}$ & 10 & 14.3 & 3 & 15.0 \\
\hline Borrowing is risky & 29 & 41.4 & 4 & 20.0 \\
\hline Too high interest rates & 4 & 5.7 & 1 & 5.0 \\
\hline $\begin{array}{l}\text { No income to service } \\
\text { the loan }\end{array}$ & 4 & 5.7 & 2 & 10.0 \\
\hline No need for a loan & 19 & 27.1 & 8 & 40.0 \\
\hline Short repayment period & 4 & 5.7 & 2 & 10.0 \\
\hline Total & $70^{\mathrm{a}}$ & 100 & $20^{\mathrm{a}}$ & 100 \\
\hline
\end{tabular}

${ }^{a}$ Total number of responses (f) may be more than 100 due to multiple responses.

crop varieties, apply fertilizers and thereby improve household income.

The farmers who did not have access to credit cited lack of assets for collateral (42 and 62\% for male- and female-headed households, respectively) and lack of a credit institution in their area (58 and 38\% for maleand female-headed households, respectively) (Figure 7). No significant difference was observed between the sex of the household head and the barriers to credit access $\left(\chi^{2}=1.166, P=0.280\right)$. Savings and Credit Cooperative Organizations (SACCO) were the main source of credit (30.8 and $31.8 \%$ for male- and female-headed households) (Table 4). All farmers who received credit used it for its primary purpose, which was mainly to buy planting material, pesticides or fungicides for male-headed households $(27.5 \%)$ or to start up a small business $(30 \%)$ for female-headed households (Table 5). Other equally important needs for credit included payment of farm labor and school fees for children. The amount of credit received varied from UGX10,000 to UGX14,000,000 in male-headed households (Table 6). Although male-headed households received higher credit amounts than femaleheaded households, the difference was not significant

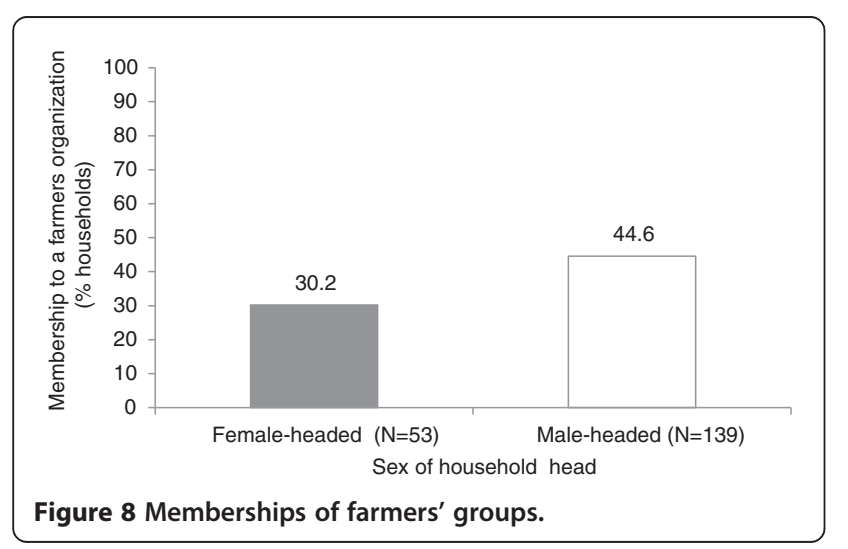

Table 8 Type of farmer organizations that household members had membership to

\begin{tabular}{|c|c|c|c|c|}
\hline \multirow{3}{*}{$\begin{array}{l}\text { Type of farmer } \\
\text { organization }\end{array}$} & \multicolumn{4}{|c|}{ Membership to farmer groups } \\
\hline & \multicolumn{2}{|c|}{$\begin{array}{l}\text { Male-headed } \\
\text { households }\end{array}$} & \multicolumn{2}{|c|}{$\begin{array}{l}\text { Female-headed } \\
\text { households }\end{array}$} \\
\hline & $f$ & Responses, \% & $f$ & Responses, \% \\
\hline Local village group & 26 & 41.9 & 7 & 43.8 \\
\hline $\begin{array}{l}\text { National Agricultural } \\
\text { Advisory Services (NAADS) } \\
\text { village group }\end{array}$ & 21 & 33.9 & 4 & 25.0 \\
\hline Farmers' cooperative/union & 11 & 17.7 & 3 & 18.8 \\
\hline Savings and credit group & 4 & 6.5 & 2 & 12.5 \\
\hline Total & $62^{a}$ & 100 & $16^{\mathrm{a}}$ & 100 \\
\hline
\end{tabular}

aTotal number of responses may be more than 100 due to multiple responses.

$(P=0.154)$. Even in households that had access to credit, the risk that comes with borrowing money from finance institutions hindered most households from acquiring cash loans (Table 7). Too much paperwork was also an equally important barrier to access to credit.

\section{Membership to and functions of farmer organizations}

Farmers were asked if any member of the household currently belonged to an agriculture-related social network such as a farmers group, farmers association or community-based organization (Figure 8). Male-headed households had significantly $(P=0.048)$ more members who belonged to a farmer organization (44.6\%) compared to female-headed households (30.2\%). Village level farmers groups were the most common type of farmer organization, attracting $41.9 \%$ and $43.8 \%$ of the male- and female-headed

Table 9 Functions of farmer organizations

\begin{tabular}{|c|c|c|c|c|}
\hline \multirow[t]{2}{*}{$\begin{array}{l}\text { Service/technology received } \\
\text { from farmers organization }\end{array}$} & \multicolumn{2}{|c|}{$\begin{array}{l}\text { Male-headed } \\
\text { households }\end{array}$} & \multicolumn{2}{|c|}{$\begin{array}{l}\text { Female-headed } \\
\text { households }\end{array}$} \\
\hline & $f$ & $\begin{array}{c}\text { Responses, } \\
\%\end{array}$ & $f$ & $\begin{array}{c}\text { Responses, } \\
\%\end{array}$ \\
\hline Labor exchange/shared labor & 10 & 7.5 & 5 & 13.9 \\
\hline $\begin{array}{l}\text { Planting material (seeds, } \\
\text { cuttings, suckers, vines) }\end{array}$ & 32 & 24.1 & 8 & 22.2 \\
\hline $\begin{array}{l}\text { Loans (cash, household items, } \\
\text { seeds) and savings }\end{array}$ & 28 & 21.1 & 10 & 27.8 \\
\hline $\begin{array}{l}\text { Training on modern farming } \\
\text { methods }\end{array}$ & 36 & 27.1 & 9 & 25.0 \\
\hline $\begin{array}{l}\text { Farm animals (chicken, turkey, } \\
\text { goats, bee hives) }\end{array}$ & 10 & 7.5 & 0 & 0.0 \\
\hline $\begin{array}{l}\text { Source market for the farmers } \\
\text { produce }\end{array}$ & 7 & 5.3 & 1 & 2.8 \\
\hline $\begin{array}{l}\text { Farm equipment (hand hoes, } \\
\text { watering cans, spray pumps, } \\
\text { axe, machete) }\end{array}$ & 7 & 5.3 & 1 & 2.8 \\
\hline $\begin{array}{l}\text { Agrochemicals (fertilizers and } \\
\text { pesticides) }\end{array}$ & 3 & 2.3 & 2 & 5.6 \\
\hline Total & $133^{a}$ & 100.0 & $36^{a}$ & 100.0 \\
\hline
\end{tabular}

${ }^{\mathrm{a}}$ Total number of responses (f) may be more than 100 due to multiple responses. 
households, respectively (Table 8). Other types of farmer organizations included cooperative unions, and savings and credit groups. Farmers received a number of services and goods geared towards promoting and multiplication of new technologies, especially in the NAADS village groups (Table 9). Services that were received most included loans and savings, seed, farm inputs and training on modern crop and livestock farming methods. Topics for training included soil conservation, income diversification, food security, poultry rearing, bee keeping, child nutrition, home sanitation, use of biogas, farming as a business, record keeping and effective use of credit money.

Farmers groups have potential in the areas of improvement of food security, creating markets and promotion of adoption of improved agricultural technologies. Female participation is however recommended because survey results from Kenya revealed that formation of farmer groups tended to favor male control of crop production and revenues [16].

\section{Conclusions and policy implications}

Both male- and female-headed households were found to have relatively equal access to agricultural information and credit. Access to- and utilization of- both agricultural information related to sweet potato cropping and credit were very low in male- and female-headed households alike. There is therefore a need for extension service providers to package integrated sweet potato management messages for better understanding and efficient use, preferably in local languages since $75 \%$ of the respondents had $\leq 7$ school years, and through mass media such as radio for utilization not only in Uganda but also in other subSaharan countries where sweet potato is grown. There is evidence of anti-female household head bias in membership to farmer organizations. The various development partners need to encourage women to join agricultural organizations. It is recommended that men receive training on gender mainstreaming and awareness, so as to appreciate the role women play in the sweet potato value chain. Future studies should examine differences in sweet potato productivity and gender roles between men and women. Also, a larger and equal sample of male- and femaleheaded households is recommended to observed agroecological zone specific differences that influence sweet potato productive resources.

\footnotetext{
Abbreviations

CIP: International potato center; FAO: Food and Agriculture Organization of the United Nations; MDG: Millennium development goal; MoFPED: Ministry of finance planning and economic development; NAADS: National agricultural advisory services; WFP: World food programme.
}

\section{Competing interests}

The authors declare that they have no competing interests.

\section{Authors' contributions}

JSO conceived and designed the study, collected and analyzed data, drafted the manuscript and coordinated the write up. JK conceived, designed and supervised all stages of the study. Both authors read and approved the manuscript.

\section{Authors' information}

JSO is a Research assistant in the Global Program of Integrated Crop and Systems Research at the International Potato Center, Kampala, Uganda. JK is Professor of Agroecology, Senior Research Scientist and Scientific Leader of the subprogram Agroecology/IPM at the International Potato Center (CIP), Lima, Peru.

\section{Acknowledgements}

The financial support of the German Federal Ministry for Economic Cooperation and Development (BMZ) is gratefully acknowledged. We thank Stella Okello Odur for her valuable comments during questionnaire development, Katja Syndikus and Ssempa Zaamu for participation in data collection. Further, we are grateful to the support of the enumerators for translating the questions into local languages and to the district agriculture officers for authorizing the surveys. The authors are also grateful for the valuable comments of Prossy Isubikaru, Richard Gibson and the two anonymous reviewers on the manuscript draft.

\section{Author details}

${ }^{1}$ Global Program of Integrated Crop and Systems Research, International Potato Center (CIP), PO Box 22274, Kampala, Uganda. ${ }^{2}$ Global Program of Integrated Crop and Systems Research, International Potato Center (CIP), Apartado 1558, Lima 12, Peru.

Received: 25 October 2013 Accepted: 12 December 2013

Published: 16 January 2014

\section{References}

1. MoFPED (Ministry of Finance, Planning and Economic Development): National Development Plan 2010/2011-2014/2015. Kampala, Uganda: Government of Uganda; 2010.

2. WFP (United Nations World Food Programme): Comprehensive Food Security \& Vulnerability Analysis (CFSVA) for Uganda. Rome, Italy: WFP; 2009.

3. CIP (International Potato Center): Facts and Figures About Sweetpotato. Lima, Peru: International Potato Center (CIP); 2010.

4. Hall AJ, Bockett GN, Nahdy S: Sweetpotato Postharvest Systems in Uganda: Strategies, Constraints and Potentials. Working paper series No. 1998-7. Lima, Peru: International Potato Centre (CIP); 1998.

5. UN Millennium Project: Investing in Development: A Practical Plan to Achieve the Millennium Development Goals. New York, NY: United Nations; 2005.

6. FAO (Food and Agriculture Organization of the United Nations): Women Feed the World - Tele Food Material. Rome, Italy: FAO; 1998.

7. Doss C: Designing agricultural technology for African women farmers: Lessons from 25 years of experience. World Dev 2001, 29:2075-2095.

8. Ibnouf FO: Challenges and possibilities for achieving household food security in the Western Sudan region: the role of female farmers. Food Sec 2011, 3:215-231.

9. Adejo PE, Idoka MH, Adejo EG: Gender issues and access to ICTs for agricultural and rural development in Dekina Local Government Area of Kogi State. J Agric Ext Rural Dev 2013, 5:77-82.

10. Oladele IO: Multilinguality of farm broadcast and agricultural information access in Nigeria. Nord J Afr Stud 2006, 15:199-205.

11. Umeta G, Lemecha F, Mume T: Survey on women access to agricultural extension services at selected districts of Mid Rift Valley of Ethiopia. J Agric Ext Rural Dev 2011, 3:51-63.

12. Okwu OJ, Umoru Bl: A study of women farmers' agricultural information needs and accessibility: a case study of Apa Local Government Area of Benue State, Nigeria. Afr J Agric Res 2009, 4:1404-1409.

13. Erbaugh JM, Donnermeyer J, Amujal M, Kidoido M: Assessing the impact of farmer field school participation on IPM adoption in Uganda. J Int Agric Ext Educ 2010, 17:5-17.

14. Bakeera SK, Pariyo G, Petzold M, Galea S, Wamala SP: Associations between Socioeconomic factors and social capital amongst child caregivers in Eastern Uganda. Rev Econ Financ 2012, 1:51-62. 
15. Obinne C: Rural women in food chain activities: a case of Ibo speaking ethnic community of Delta State, Nigeria. Agrores 1995, 1:35-40.

16. Fischer E, Qaim M: Gender, agricultural commercialization, and collective action in Kenya. Food Sec 2012, 4:441-453.

17. Protz M: Developing sustainable agricultural technologies with rural women in Jamaica: A participatory media approach. Reading, UK: University of Reading; 1997.

18. Okonya JS, Syndikus K, Kroschel J: Farmers' perception of and coping strategies to climate change: evidence from six Agro-ecological zones of Uganda. J Agric Sci 2013, 5:252-263.

19. SAS Institute Inc: The SAS System for Windows v9.2. Cary, NC: SAS Institute Inc; 2008.

20. Bashaasha B, Mwanga ROM, Ocitti P'Obwoya C, Ewell PT: Sweetpotato in Farming and Food Systems of Uganda: A Farm Survey Report. Kampala, Uganda: International Potato Center (CIP) and National Agricultural Research Organization (NARO); 1995.

21. Onwueme IC: The Tropical Tuber Crops: Yams, Cassava, Sweet Potato, and Cocoyams. New York, NY: Wiley, John \& Sons Inc; 1978.

22. Andrade M, Barker I, Cole D, Dapaah H, Elliott H, Fuentes S, Grüneberg W, Kapinga R, Kroschel J, Labarta R, Lemaga B, Loechl C, Low J, Lynam J, Mwanga R, Ortiz O, Oswald A, Thiele G: Unleashing the Potential of Sweet potato in Sub-Saharan Africa: Current Challenges and Way Forward. Kampala, Uganda: International Potato Center (CIP); 2009.

23. Fischler M, Wortmann CS: Green manures for maize-bean systems in Eastern Uganda: agronomic performance and farmer perceptions. Agroforest Syst 1999, 47:123-138.

24. Okonya JS, Maass BL: Potential of cowpea genotypic mixtures to increase yield stability in subsistence agriculture: preliminary results. Int $J$ Agron. in press.

25. Finckh MR, Gacek ES, Goyeau H, Lannou C, Merz U, Mundt CC, Munk L, Nadziak J, Newton CA, Vallavieille-Pope C, Wolfe MS: Cereal variety and species mixtures in practice, with emphasis on disease resistance. Agronomie 2000, 20:813-837.

26. Kashaija IN, Wagoire WW: Farming Systems and Livelihood Analysis of the South-western Highlands Agro-ecological Zone: A Report. Kabale, Uganda: Kachwekano Zonal Agricultural Research and Development Institute (KaZARDI); 2008.

27. Abidin PE: Sweet potato Breeding for Northeastern Uganda: Farmer Varieties, Farmer-Participatory Selection, and Stability of Performance. PhD thesis. Wageningen, The Netherlands: Agricultural University of Wageningen; 2004.

28. Ibnouf FO: The value of women's indigenous knowledge in food processing and preservation for achieving household food security in rural Sudan. J Food Res 2012, 1:238-253.

29. World Bank: Food and Agriculture Organization, International Fund for Agricultural Development: Gender in Agriculture: Sourcebook. Washington, DC: World Bank Publications; 2009.

30. Yakubu DH, Abubakar BZ, Atala TK, Muhammed A: Use of information and communication technologies among extension agents in Kano State, Nigeria. J Agric Ext 2013, 17:162-173.

31. UNHS (Uganda National Household Survey): Abridged Report for the Socioeconomic Module. Kampala, Uganda: Uganda Bureau of Statistics (UBOS); 2010.

32. Mgbada JU: Effectiveness of information sources on improved farming practices to women farmers in Enugu State, Nigeria. Glob Approach Ext Pract 2006, 2:67-78.

33. Ragasa C, Berhane G, Tadesse F, Taffesse AS: Gender Differences in Access to Extension Services and Agricultural Productivity. Ethiopia Strategy Support Program II Working Paper 49. Washington, DC: International Food Policy Research Institute (IFPRI); 2012.

34. de Janvry A, Sadoulet E: Income strategies among rural households in Mexico: the role of off-farm activities. World Dev 2001, 29:467-480

35. Fernandez-Cornejo J, Mishra A, Nehring R, Hendricks C, Southern M, Gregory A: Off-Farm Income, Farm Economic Performance, and Technology Adoption. Economic Research Report Number 36. Washington, DC: Department of Agriculture; 2007.
36. Woldehanna T: Economic Analysis and Policy Implications of Farm and Off-farm Employment: A Case Study in the Tigray Region of Northern Ethiopia. PhD Thesis. Wageningen, The Netherlands: Agricultural University of Wageningen; 2000

37. World Bank: Engendering Development Through Gender Equality in Rights, Resources and Voice. World Bank Policy Research Report 21776. Washington, DC and London, UK: World Bank and Oxford University Press; 2001.

38. Fletschner D: Rural women's access to credit: market imperfections and intrahousehold dynamics. World Dev 2009, 37:618-631.

\section{doi:10.1186/2048-7010-3-1}

Cite this article as: Okonya and Kroschel: Gender differences in access and use of selected productive resources among sweet potato farmers in Uganda. Agriculture \& Food Security 2014 3:1.

\section{Submit your next manuscript to BioMed Central and take full advantage of:}

- Convenient online submission

- Thorough peer review

- No space constraints or color figure charges

- Immediate publication on acceptance

- Inclusion in PubMed, CAS, Scopus and Google Scholar

- Research which is freely available for redistribution

Submit your manuscript at www.biomedcentral.com/submit
C Biomed Central 